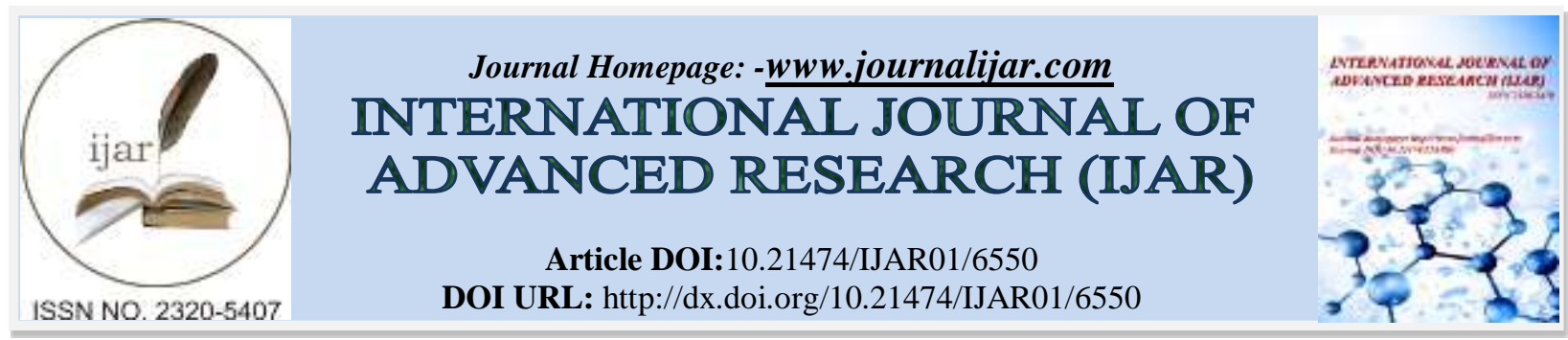

RESEARCH ARTICLE

\title{
PHYSICOCHEMICAL AND MICROBIAL QUALITY OF THAMAR CITY DRINKING WATER, YEMEN
}

\author{
Abedelmalek M. Amran ${ }^{1}$, Adel A. A. Omer. Amin M. A. Alwasaei ${ }^{3}$ and Abdulaziz. A.Y. Abass ${ }^{4}$. \\ Department of Biotechnology and Food Technology, Faculty of Agriculture and Veterinary Medicine, Thamar Univ \\ ersity, Yemen.
}

\section{Manuscript Info}

Manuscript History

Received: 16 December 2017

Final Accepted: 18 January 2018

Published: February 2018

Keywords:-

Drinking water- Microbial quality -

Physicochemical parameters

Chlorination.

\section{Abstract}

This study aimed to evaluate the microbial, chemical and physical quali ty of drinking water in Thamar city, Yemen and assess the water chlori nation treatment effectiveness in water microbial quality. Samples inclu ded water from wells, main reservoirs and distribution systems from ho usehold tanks in some zones. The results showed that total bacterial cou nt was above the WHO and Yemeni standards which ranged between 3 $3-52 \times 10^{3}, 173-196 \times 10^{3}$ and $52-180 \times 10^{3} \mathrm{CFU} / \mathrm{ml}$ in wells, main reservoirs and household tanks water respectively, while total coliform bacteria didn't found in all wells and main reservoirs water samples but it was present in all water samples from household tanks except one gro up of regions included in this study which ranged between 4- 23 MPN/ $100 \mathrm{ml}$ of water. Water treatment with sodium hypochlorite at $2 \mathrm{mg} / \mathrm{l} \mathrm{r}$ educed its microbial load and improved its microbial quality. The result $\mathrm{s}$ also showed that all chemical and physical parameters of water sampl es were within WHO and Yemeni standards value except total alkalinit y level which was above these standards.

Copy Right, IJAR, 2018,. All rights reserved.

\section{Introduction:-}

Water has great importance in life where all organisms cannot live without it, and human needs around 2-3 litres/day on average, and the quality of drinking water is a priority, especially in developing countries.

Water can be obtained from a number of sources including rivers, springs, lakes, ground water and desalinated sea w ater, and the quality of water vary according to the source water quality and treatment applied before consumption $b$ ecause the water is a major source of many diseases that afflict people in Africa, Asia and Latin America, especially when proper treatment is not available in particular the water disinfection process of pathogenic microbes, and drin king water contain different species of bacteria that have the ability to human injury serious diseases that affect the health and drinking contaminated water results in thousands of deaths every day, mostly in children under five years, in developing countries, (WHO, 2006).

Potable water is defined as water that is free from disease producing microorganisms and chemical substances deleterious to health, (Ihekoronye \& Ngoddy, 1985).

Before water can be described as potable, it has to comply with certain physical, chemical and microbiological standards, which are designed to ensure that the water is potable and safe for drinking, (Tebutt, 1983). 
There are two types of water pollution, namely, point source pollution- which occurs as a result of release of harmful substances directly into the body of water, and non-point source pollution-which occurs as a result of indirect introduction of pollution into water bodies/sources from the environment, (Kerker, 2003).

Shittu et al., (2008) found that the total bacteria count in wells, rivers and streams water that used for drinking and s wimming purposes in Abeokuta state - Nigeria was ranged between $6.3 \times 10^{6}$ and $2.01 \times 10^{7} \mathrm{CFU} / \mathrm{ml}$, and the highe st load was in rivers water, while the least was in the wells water at $1.0 \times 10^{2} \mathrm{CFU} / \mathrm{ml}$, and the total coliform bacteri a ranged between 1600 and more than 1800 MPN/100 ml.

Antony \& Renuga, (2012) microbiological study for Ananthanar channel water which is used for drinking and house hold purposes in many villages in India, reported that faecal coliform bacteria count was between 12 - 180 MPN/100 $\mathrm{ml}$ of water.

Whereas Ell-Amin et al. (2012) study reported that total bacteria count in Khartoum drinking water, Sudan was betw een $4 \times 10^{2}$ and $4.5 \times 10^{4} \mathrm{CFU} / \mathrm{ml}$, while coliform bacteria count was between $23-1100 \mathrm{CFU} / \mathrm{ml}$.

To prevent transmission of pathogens to humans by water, it is typically used a suitable method for water sterilizatio n.

Water disinfection treatment has important as final stages in drinking water treatment to prevent disease transmissio $\mathrm{n}$ through the water supply system, and the chlorination process is the most widely used methods of water disinfectio n, (Goel \& Bouwer, 2004).

Almeida et al., (2015) mentioned that quality of treated water was better than untreated water and the treatment applied on drinking-water was effective, thereby, reducing the microbial contamination in environmental waters, thus, the remedy to water contamination is the treatment of all water supply sources.

As a result of lack in physiochemical and microbial studies for drinking water and its sources in Thamar city, this stu dy was conducted which aimed to estimate physiochemical properties and microbial quality of drinking water at hou sehold tanks, main reservoirs and wells of water in Thamar city and compare the results with Yemeni and WHO stan dards value for drinking water and evaluation of water chlorination treatment in improving of drinking water microb ial quality.

\section{Materials and methods:- \\ Sampling:-}

Water samples were collected from wells (7 wells), water main reservoirs (3 tanks) and water distribution systems fr om some household tanks in many zones in Thamar city (the city was divided into 4 groups (A, B, C, D) included 24 zones), the study lasted three months.

Samples were carried in sterile plastic bags to the laboratory of biotechnology and food Technology Department, wh ere microbiological and physicochemical tests were draw.

\section{Microbiological analysis of water samples:- \\ Total bacteria counts:-}

Total bacteria count was performed by Plate Count Agar (PCA) method and decimal dilution series for samples with sterile saline $(0.9 \%$ sodium chloride) and $1 \mathrm{ml}$ of each dilution was plating in plate count agar in duplicate plates and incubated at $37^{\circ} \mathrm{C}$ for $24-48 \mathrm{hr}$, (APHA, 1989).

\section{Total Coliform counts:-}

Estimation of total coliform in drinking water samples were done by the Most Probable Number method (MPN) in $\mathrm{t}$ hree steps:

\section{Presumptive test:-}

Most Probable Number (MPN) bacteria present in water sample has been estimated by using tubes containing Lacto se Broth (3 tubes) and incubated at $37 \mathrm{C}^{\circ}$ for 48 hours. 


\section{Confirmatory test:-}

Confirmatory test was performed by using Eiosine methylene blue (EMB) and incubated at $37 \mathrm{C}^{\circ}$ for 48 hours.

\section{Complementary test:-}

Tubes containing Lactose Broth were used to perform this test and incubated at $37 \mathrm{C}^{\circ}$ for 48 hours.

The numbers of the positive tubes per dilutions were determinate and calculated the MPN index from the MPN table s, (Pepper and Gerba, 2004).

\section{Physicochemical analysis of water samples:-}

Physical analysis:-

Water $\mathrm{pH}$, total dissolve salts (TDS) and electrical conductivity (CE) were determined by TDS \& CE meter, Hanna Company, while turbidity was measured by using HACH Dr / 890 Colorimeter, HACH Company, USA.

\section{Chemical analysis:-}

The chemical parameters of water were measured by using HACH Dr/890 Colorimeter, HACH Company, USA.

\section{Water chlorination:-}

Water sample treated with sodium hypochlorite at $0.2 \mathrm{mg} / \mathrm{l}$ for $10-30$ minutes and total bacteria and total colifom c ounts were determinate after this treatment and compared it with the counts of these bacteria in water before the chlo rination.

\section{Results and discussions:- \\ Bacteriological analysis:- \\ Total bacteria counts:- \\ Wells and main reservoirs water:-}

Results in table (1) shows the total bacteria counts for wells and main reservoirs water in Thamar city, and it's indica ted that the contamination in wells water was lower than main reservoirs water and it's also showed that the total bac teria counts have been varied from sample to another be due the variation in the place of wells which the wells that a re in the same residential density had the same level of contamination and the sample from the wells that located in $\mathrm{d}$ ensely populated residential zones have relatively high in bacteria count.

The total bacterium counts in wells water was ranged between 33 and $58 \times 10^{3} \mathrm{CFU} / \mathrm{ml}$.

Table 1:- Total bacteria counts in wells and main reservoirs water of Thamar city.

\begin{tabular}{|l|l|l|l|}
\hline The wells. & $\begin{array}{l}\text { Total bacteria counts. } \\
(\mathrm{CFU} / \mathrm{ml})\end{array}$ & Water main reservoirs. & $\begin{array}{l}\text { Total bacteria counts. } \\
(\mathrm{CFU} / \mathrm{ml})\end{array}$ \\
\hline Almohafezah & $47 \times 10^{3}$ & Thamer & $196 \times 10^{3}$ \\
\hline Alseaid & $33 \times 10^{3}$ & Herran & $182 \times 10^{3}$ \\
\hline Alastad alryady & $58 \times 10^{3}$ & Algarn & $173 \times 10^{3}$ \\
\hline Mahata alazeraq & $45 \times 10^{3}$ & & \\
\hline Shaeibah & $52 \times 10^{3}$ & & \\
\hline Aldurah & $36 \times 10^{3}$ & & \\
\hline Algeded & $41 \times 10^{3}$ & & \\
\hline
\end{tabular}

The table (1) also shows total bacteria counts in water samples taken from main reservoirs in the city and its microbi al loads was higher than the wells water, which indicates water contamination was occurred during water pumping fr om wells to the main reservoirs or may be due a deficiency in main reservoirs annual cleaning process, because the a nnual cleaning process for water tanks can protect water from pollution as mentioned by (Levesque et al., 2008).

The total bacteria counts in main reservoirs water was ranged between 173 and $196 \times 10^{3} \mathrm{CFU} / \mathrm{ml}$.

The total bacteria counts in all main reservoirs and wells water samples were without of WHO and Yemeni standard $\mathrm{s}$ value of drinking water.

\section{Household tanks water:-}

Table (2) shows the results of bacteriological evolution for household tanks water in Thamar city, and the results of group A and B indicated that presence of pollution in water samples more than other groups which total bacteria cou nts were between 123 and $180 \times 10^{3} \mathrm{CFU} / \mathrm{ml}$. 
While total bacteria counts for water samples in group C and D were between 57 and $112 \times 10^{3} \mathrm{CFU} / \mathrm{ml}$ which was 1 ower than A and B groups.

This may be a result of water contamination that occurred in distribution system pipes where sewage water pipes pas sing near it and that may lead to pollution, as well as occurrence of rust and holes in the distribution system pipes lea ding to allow microorganisms interning to distribution system pipes from the surrounding sources.

These findings are in agreement with the results of Eze \& Madumere, (2012), who showed that microbial load of wa ter in Abia state, Nigeria was between 3.93 and $6.83 \times 10^{4} \mathrm{CFU} / \mathrm{ml}$.

but it was less than the results that found by Sunday et al.,( 2014) who found that the microbial load of water used in domestic purposes in Edo state, Nigeria was 1.8 and $2.6 \times 10^{5} \mathrm{CFU} / \mathrm{ml}$ which more than WHO standard value.

But its more than the results founded by Kolawole and Obueh, ( 2015) who found that total heterotrophic bacteria co unts in tap water of Utagba-Uno, Nigeria was $1.2 \times 10^{2} \mathrm{CFU} / \mathrm{ml}$.

But these results are without WHO and Yemeni standards value for drinking water which identified microbial load i n drinking water should not more than $1 \times 10^{2} \mathrm{CFU} / \mathrm{ml}$.

Table 2:- Total bacteria count in household tanks water from Thamar city zones.

\begin{tabular}{|c|c|c|c|c|c|c|c|}
\hline $\begin{array}{l}\text { Zone } \\
\text { group }\end{array}$ & $\begin{array}{l}\text { Total bact } \\
\text { eria count } \\
(\mathrm{CFU} / \mathrm{ml}) \text {. }\end{array}$ & Range & Mean & $\begin{array}{l}\text { Zone } \mathrm{g} \\
\text { roup }\end{array}$ & $\begin{array}{l}\text { Total bacter } \\
\text { ia count (CF } \\
\mathrm{U} / \mathrm{ml}) \text {. }\end{array}$ & Range & Mean \\
\hline \multirow[t]{8}{*}{$\mathbf{A}$} & $180 \times 10^{3}$ & \multirow{8}{*}{$\begin{array}{l}169-180 \times \\
10^{3}\end{array}$} & \multirow{8}{*}{$\begin{array}{l}175 \pm 7.49 \\
10^{3}\end{array}$} & \multirow[t]{8}{*}{$\mathbf{C}$} & $98 \times 10^{3}$ & \multirow{8}{*}{$\begin{array}{l}78-112 \\
\times 10^{3}\end{array}$} & \multirow[t]{8}{*}{$93.62 \pm 4.59 \times 10^{3}$} \\
\hline & & & & & $95 \times 10^{3}$ & & \\
\hline & $169 \times 10^{3}$ & & & & $103 \times 10^{3}$ & & \\
\hline & & & & & $91 \times 10^{3}$ & & \\
\hline & & & & & $78 \times 10^{3}$ & & \\
\hline & $178 \times 10^{3}$ & & & & $89 \times 10^{3}$ & & \\
\hline & & & & & $112 \times 10^{3}$ & & \\
\hline & & & & & $83 \times 10^{3}$ & & \\
\hline \multirow[t]{9}{*}{ B } & $170 \times 10^{3}$ & \multirow{9}{*}{$\begin{array}{l}123-170 \times \\
10^{3}\end{array}$} & \multirow{9}{*}{$\begin{array}{l}145.4 \pm 5.80 \\
10^{3}\end{array}$} & \multirow[t]{9}{*}{ D } & $62 \times 10^{3}$ & \multirow{9}{*}{$\begin{array}{l}52-92 \times \\
10^{3}\end{array}$} & \multirow{9}{*}{$\begin{array}{l}74.75 \pm 4.59 \times \\
10^{3}\end{array}$} \\
\hline & & & & & $57 \times 10^{3}$ & & \\
\hline & $157 \times 10^{3}$ & & & & $75 \times 10^{3}$ & & \\
\hline & & & & & $83 \times 10^{3}$ & & \\
\hline & $123 \times 10^{3}$ & & & & $92 \times 10^{3}$ & & \\
\hline & & & & & $86 \times 10^{3}$ & & \\
\hline & $139 \times 10^{3}$ & & & & $52 \times 10^{3}$ & & \\
\hline & & & & & \multirow[t]{2}{*}{$91 \times 10^{3}$} & & \\
\hline & $138 \times 10^{3}$ & & & & & & \\
\hline
\end{tabular}

Total coliform counts:-

Wells and main reservoirs water:-

Total coliform presumptive test results for well and main reservoirs water showed that all water samples were free fr om total coliform, despite presence turbidity in the test tubes, but did not notice gas production which indicates the $p$ resence of total coliform especially E. coli that produce a gas. These results may be due to the high depth of water $\mathrm{w}$ ells which reach more than 100 meters as mentioned by Water Foundation of Thamar governorate.

These findings were within WHO and Yemeni standard value for drinking water, where it's required that total colifo rm count in drinking water shall not be exceed than 0 CFU/100 ml.

Household tanks water:-

Table (3) showed that the results of complementary test in three regions groups in Thamar city which it results were positive in the confirmatory tests, and a similar results for probability test was found where gas production and chan ge in the colour of the media, total coliform counts were $23 \mathrm{MPN} / 100 \mathrm{ml}$ in group A and $9 \mathrm{MPN} / 100 \mathrm{ml}$ in group B, while lowest count was in the water samples from group $\mathrm{C}$ which reaching $4 \mathrm{MPN} / 100 \mathrm{ml}$ of water. 
Tale 3:- Complementary test for total coliform in water samples from household tanks in Thamar city zones.

\begin{tabular}{|c|c|c|c|c|c|c|c|c|c|}
\hline \multirow[t]{2}{*}{$\begin{array}{l}\text { Zone gro } \\
\text { up }\end{array}$} & \multicolumn{3}{|c|}{$\begin{array}{l}\text { Number of Positive Tubes in } \\
\text { Dilutions. }\end{array}$} & \multirow[t]{2}{*}{$\begin{array}{l}\text { MPN /100 } \\
\mathrm{ml}\end{array}$} & \multirow[t]{2}{*}{$\begin{array}{l}\text { Zone gro } \\
\text { up }\end{array}$} & \multicolumn{3}{|c|}{$\begin{array}{l}\text { Number of Positive Tubes in } \\
\text { Dilutions }\end{array}$} & \multirow[t]{2}{*}{$\begin{array}{l}\text { MPN /100 } \\
\mathrm{ml}\end{array}$} \\
\hline & $10^{-1}$ & $10^{-2}$ & $10^{-3}$ & & & $10^{-1}$ & $10^{-2}$ & $10^{-3}$ & \\
\hline \multirow[t]{3}{*}{ A } & 3 & 0 & 0 & 23 & \multirow[t]{8}{*}{ C } & 1 & 0 & 0 & 4 \\
\hline & 3 & 0 & 0 & 23 & & 1 & 0 & 0 & 4 \\
\hline & 3 & 0 & 0 & 23 & & 1 & 0 & 0 & 4 \\
\hline \multirow[t]{5}{*}{ B } & 2 & 0 & 0 & 9 & & 1 & 0 & 0 & 4 \\
\hline & 2 & 0 & 0 & 9 & & 1 & 0 & 0 & 4 \\
\hline & 2 & 0 & 0 & 9 & & 1 & 0 & 0 & 4 \\
\hline & 2 & 0 & 0 & 9 & & 1 & 0 & 0 & 4 \\
\hline & 2 & 0 & 0 & 9 & & 1 & 0 & 0 & 4 \\
\hline
\end{tabular}

These results are consistent with the results of Kurup et al. (2010) study on the water in Georgetown who found a hi gh level of contamination by coliform bacteria in water sources and city distribution systems which was without WH O standard and it reached to more than $250 \mathrm{CFU} / \mathrm{ml}$, and also its consistent with the results of Pavendan et al., (2011 ) study for the water from various sources in south India, who found that total coliform count in the most cases was higher than $250 \mathrm{CFU} / 100 \mathrm{ml}$.

As well as consistent with the study of Sunday et al., (2014), who found that total coliform count in water that used in homes in Edo state -Nigeria was between 7 and $14 \mathrm{MPN} / 100 \mathrm{ml}$ which was more than WHO limit, and with the results of Kolawole and Obueh, (2015) study which showed that total coliform count in the tap water of UtagbaUno, Nigeria was $18 \mathrm{MPN} / 100 \mathrm{ml}$.

Its consistent also with the results of Ell-Amin et al.,(2012), study who found that coliform bacteria count in Khartou $\mathrm{m}$ drinking water, Sudan were between 23 and $1100 \mathrm{CFU} / \mathrm{ml}$.

These results were without the WHO standard which recommended that total coliform count in drinking water shall not be exceed than $0 \mathrm{CFU} / 100 \mathrm{ml}$, so such water needs to be treated before it used in order to reduce water microbia 1 contamination.

\section{Water chlorination treatment:-}

\section{Total bacteria counts:-}

Results in the table (4) showed that the effective of water chlorination treatment at $2 \mathrm{mg} / \mathrm{l}$ caused a reduction in the $\mathrm{t}$ otal bacteria counts from $10^{3}$ to $10^{1} \mathrm{CFU} / \mathrm{ml}$ which indicated that effectiveness of chlorine treatment in water microb ial load reduction.

These findings are consistent with Bishankha et al., (2013) study which illustrated that the presence of free chlorine i $\mathrm{n}$ the water has reduced the total bacteria count and an inverse relationship between total bacteria count and free chlo rine concentration in the water was found and the Log of inactivation for various organisms with the chlorine residu al concentration at $0.2 \mathrm{mg} / \mathrm{l}$ were found to be less than 30 minute and greater than 60 minute for all eight different ty pes of organisms tested.

Table 4:- Effect of water chlorination treatment in total bacteria counts.

\begin{tabular}{|l|l|l|}
\hline \multirow{2}{*}{ Sample No. } & Total bacteria count $(\mathrm{CFU} / \mathrm{ml})$ & \\
\cline { 2 - 3 } & Before chlorination & After chlorination \\
\hline $\mathbf{1}$ & $263 \times 10^{3}$ & $42 \times 10^{1}$ \\
\hline $\mathbf{2}$ & $196 \times 10^{3}$ & $35 \times 10^{1}$ \\
\hline $\mathbf{3}$ & $178 \times 10^{3}$ & $25 \times 10^{1}$ \\
\hline
\end{tabular}

Total coliform counts:-

Table (5) showed effect of water chlorination treatment in total coliform counts which indicated that efficiency of chlorination process in eliminating coliform bacteria, and water chlorination treatment led to eradicate coliform bacteria in water samples where all MPN tubes were appeared a negative results after water chlorination treatment the MPN index reached to $<3 / 100 \mathrm{ml}$. 
Table 5:- Effect of water chlorination treatment in total coliform counts.

\begin{tabular}{|c|c|c|c|c|c|c|c|c|c|}
\hline \multirow{3}{*}{$\begin{array}{l}\text { Sample N } \\
\text { o. }\end{array}$} & \multicolumn{4}{|c|}{ Before chlorination } & \multirow{3}{*}{$\begin{array}{l}\text { Sample N } \\
\text { o. }\end{array}$} & \multicolumn{4}{|c|}{ After chlorination } \\
\hline & \multicolumn{3}{|c|}{$\begin{array}{l}\text { Number of Positive Tubes in } \\
\text { Dilutions. }\end{array}$} & \multirow[t]{2}{*}{$\begin{array}{l}\text { MPN } / 10 \\
0 \mathrm{ml}\end{array}$} & & \multicolumn{3}{|c|}{$\begin{array}{l}\text { Number of Positive Tubes in } \\
\text { Dilutions. }\end{array}$} & \multirow[t]{2}{*}{$\begin{array}{l}\text { MPN } / 10 \\
0 \mathrm{ml}\end{array}$} \\
\hline & $10^{-1}$ & $10^{-2}$ & $10^{-3}$ & & & $10^{-1}$ & $10^{-2}$ & $10^{-3}$ & \\
\hline 1 & 3 & 1 & 1 & 75 & 1 & 0 & 0 & 0 & $<3$ \\
\hline 2 & 2 & 1 & 0 & 15 & 2 & 0 & 0 & 0 & $<3$ \\
\hline 3 & 2 & 1 & 1 & 20 & 3 & 0 & 0 & 0 & $<3$ \\
\hline
\end{tabular}

Physicchemical parameters of water:-

Table (6) shows the physical and chemical parameters of drinking water in Thamar city, and these results confirmed that all physical parameters of water were within the limits of WHO and Yemeni standard for drinking water, where $\mathrm{pH}$ value was 8.05 , total dissolve salts was $180-195 \mathrm{mg} / 1$ of water, while the electrical conductivity was $391 \mu \mathrm{s} / \mathrm{cm}$ and water turbidity was 1 NTU.

The table (6) also shows chemical parameters of water that have been studied, and all chemical parameters of water were within WHO and Yemeni standard for drinking water (YSMO, 2005) except the total alkalinity that was $126 \mathrm{~m}$ $\mathrm{g} / \mathrm{ml}$ which it above WHO and Yemeni standards and this high value of total alkalinity may be due the high depth of water wells.

Table 6:- physicochemical parameters of drinking water in Thamar city.

\begin{tabular}{|l|l|l|l|}
\hline Water parameters & $\begin{array}{l}\text { Thamar city drinking wa } \\
\text { ter }\end{array}$ & WHO standard & Unit \\
\hline $\mathrm{pH}$ & 8.05 & $6.5-8.5$ & - \\
\hline TDS & $180-195$ & $500-1000$ & $\mathrm{ppm}$ \\
\hline EC & $360-391$ & $450-1500$ & $\mu \mathrm{s} / \mathrm{cm}$ \\
\hline Turbidity & 1 & $1-5$ & $\mathrm{NTU}$ \\
\hline Nitrate & 21.6 & $10-50$ & $\mathrm{mg} / \mathrm{l}$ \\
\hline Sulphate & 8 & $200-400$ & $\mathrm{mg} / \mathrm{l}$ \\
\hline Total hardness & 140 & $100-500$ & $\mathrm{mg} / \mathrm{l}$ \\
\hline Iron & 0.04 & $0.3-1$ & $\mathrm{mg} / \mathrm{l}$ \\
\hline Total alkalinity & 126 & 100 & $\mathrm{mg} / \mathrm{l}$ \\
\hline Bicarbonate & 220 & $100-250$ & $\mathrm{mg} / \mathrm{l}$ \\
\hline Chloride & 54 & 250 & $\mathrm{mg} / \mathrm{l}$ \\
\hline Phosphate & 0.12 & $0.4-5$ & $\mathrm{mg} / \mathrm{l}$ \\
\hline Calcium & 100 & $75-200$ & $\mathrm{mg} / \mathrm{l}$ \\
\hline Magnesium & 42 & $30-150$ & $\mathrm{mg} / \mathrm{l}$ \\
\hline
\end{tabular}

These results are similar the results founded by Werkneh et al., (2015) in his study for physicochemical quality of dr inking water in Jigjiga town- Ethiopia, which all water parameters were within drinking water standard except EC a nd total hardness which was above these standard and its value was $1143 \mu \mathrm{s} / \mathrm{cm}$ and $362.67 \mathrm{mg} / 1$ respectively.

\section{Conclusions:-}

1. High total bacteria counts were found in all water samples which above the WHO and Yemeni standard values.

1. Contamination with coliform bacteria was found in some samples from household tanks but wells and main rese rvoirs water samples were free.

2. Water from wells that located in high population density region had higher pollution than water from wells locat ed in a low population density region.

3. All physical and chemical water parameters were within WHO and Yemeni standards except total alkalinity whi ch above these standards.

4. Annual cleaning and disinfection process for main reservoirs, water chlorination treatment and maintenance of distribution systems pipes should be apply in order to improve the microbial quality of water. 


\section{References:-}

1. Almeida, J.; Félix, A.; Figueiredo. R. and Almeida, A. (2015). Drinking-water microbiological quality survey in the District of Aveiro (Portugal): a nine-year surveillance study (2000-2008). Academia Journal of Scientific Research, 3(3).

2. Antony, R. M. and Renuga, F. B. (2012). Microbiological analysis of drinking water quality of Ananthanar channel of Kanyakumari district, Tamil Nadu, India. An Interdisciplinary Journal of Applied Science: 7(2). (http://dx.doi.org/10.4136/ambi-agua.881).

3. APHA, (1998). Standard method for the examination of water and waste water, $20^{\text {th }}$ edition, American Public Health Association (A.P.H.A. American Association (AWWA), and Water Pollution Control Federation (WPCF), Washington, D.C., USA .1998).

4. Bishankha, S.; Bhatta, D. R.; Joshi, D. R. and Joshi, T. P. (2013). Assessment of microbial quality of chlorinated drinking tap water and susceptibility of gram negative bacterial isolates towards chlorine. Kathmandu University Journal of Science, Engineering and Technology, 9(1): 222-229.

5. Ell-Amin, A. M.; Sulieman, A. E. and El-Khalifa, E. A. (2012). Microbiological assessment of drinking water quality in wad-medani \& Khartoum states. Sixteenth International Water Technology Conference, IWTC 16, 2012, Istanbul, Turkey.

6. Eze, S. O. and Madumere, I. C. (2012). Physicochemical and microbiological analysis of water bodies in Uturu, Abia state-Nigeria. Asian journal of natural \& applied sciences, 1(4).

7. Goel, S. and Bouwer, E. J. (2004). Factors influencing inactivation of Klebsiella pneumonia by chlorine and chloramines. Water Research, 38, 301.

8. Ihekoronye, A.I and Ngoddy, P.O. (1985). Integrated food science and technology for tropics. Oxford: Macmillan Press, pp. 95-195.

9. Kerker, P. S.; Desshpande, L. S. and Keul, S. N. (2003). Control of non-point sewage pollution of water resources. Journal of India Environmental Management. 30:20 - 23.( C. F. Amaka, D. D. (2014).

10. Kolawole, S. E. and Obueh, H. O. (2015). Evaluation of the minerals, heavy metals and microbial compositions of drinking water from different sources in Utagba-Uno, Nigeria. ISABB- Journal of Health and Environmental Science, 2(2): 6- 10.

11. Kurup, R.; Persaud, R.; Caesar, J. and Raja, V. (2010). Microbiological and physiochemical analysis of drinking water in Georgetown, Guyana. Nature and Science. 8(8).

12. Levesque, B.; Perge, D.; Watkinson, E.; Maguire, Bissonnette, L.; Gingras, S.; Rouja, P.; Bergeron, M. G.; and Dewailly, E. (2008). Assessment of microbiological quality of drinking water from household tanks in Bermuda. Can. J. of Microbiology, (54).

13. Pavendan, P. S.; Selvan, A. and rajasekaran, C. S. (2011). Physicochemical and microbial assessment of drinking water from different water sources of Tiruchirappalli District, South India. European Journal of Experimental Biology, 1 (1):183-189.

14. Pepper, I.L. and Gerba. C.P. (2004). Environmental Microbiology. A Laboratory Manual. Second edition. Elsevier Academic Press.

15. Shittu, O.B.; Olaitan, J.O. and Amusa, T.S. (2008). Physicochemical and bacteriological analyses of water used for drinking and swimming purposes in Abeokuta, Nigeria. African Journal of Biomedical Research, 11: $285-290$.

16. Sunday, J. J.; Spencer, N. C. O.; Kingsley, O.; Edet, A. O. and Amaka, D. D. (2014). Physicochemical and microbiological properties of water samples used for domestic purposes in Okada town, Edo state, Nigeria. Int. J. Curr. Microbiol. App. Sci . 3(6): 886-894.

17. Tebutt, T.H.Y. (1983). Principles of Quality Control. England: Pergamon, p.232.

18. Werkneh, A. A.; Medhanit, B. Z.; Abay, A. K. and Damte, J. Y. (2015). Physicochemical Analysis of Drinking Water Quality at Jigjiga City, Ethiopia. American Journal of Environmental Protection, 4(1): 29-32.

19. World Health Organization (WHO). (2006). Guidelines for Drinking water quality, Volume 1: $3^{\text {rd }}$ edition, WHO Press, Switzerland.

20. (YSMO) Yemeni standards and meteorological organization. (2005). drinking water standard. 